\title{
EFFECTS OF OXALATE AND HUMIC ACID ON ARSENATE SORPTION BY AND DESORPTION FROM A CHINESE RED SOIL
}

\author{
LEI LUO, SHUZHEN ZHANG, XIAO-QUAN SHAN, YONG-GUAN ZHU \\ State Key Laboratory of Environmental Chemistry and Ecotoxicology, Research Center for \\ Eco-Environmental Sciences, Chinese Academy of Sciences, P. O. Box 2871, Beijing 100085, China \\ (e-mail:szzhang@mail.rcees.ac.cn)
}

(Received 8 February 2006; accepted 26 April 2006)

\begin{abstract}
Studies on arsenate $(\mathrm{As}(\mathrm{V}))$ sorption and desorption have been mainly limited to soil minerals and sorption and desorption reactions in whole soils are poorly understood. In this study the sorption of $\mathrm{As}(\mathrm{V})$ by and phosphate-induced desorption from a Chinese red soil were studied in the presence of oxalate and humic acid (HA). Arsenate was strongly sorbed mainly through ligand exchange reactions on the soil. Arsenate sorption decreased in the presence of oxalate or HA. Oxalate and $\mathrm{HA}$ influenced $\mathrm{As}(\mathrm{V})$ sorption mainly by competing for sorption sites and reducing sorption sites, and oxalate could also decrease sorption through dissolving clay minerals. Oxalate and HA could also facilitate $\mathrm{As}(\mathrm{V})$ desorption from the soil. Both sorption and desorption kinetics were two stage processes. Sorption kinetics conducted from $0.2-840$ h showed that As(V) sorption increased with increasing residence time. Sorption equilibrium was retarded and the maximum sorption decreased in the presence of oxalate or HA. Phosphate-induced desorption kinetics conducted on the soil with $24 \mathrm{~h}$ and $840 \mathrm{~h}$ of sorption equilibrium time showed a significant effect of equilibrium time on $\mathrm{As}(\mathrm{V})$ desorption. The presence of oxalate or HA during the sorption process resulted in more $\mathrm{As}(\mathrm{V})$ desorption. Due to the degradation of oxalate, soil treated with oxalate and with a sorption equilibrium time of $840 \mathrm{~h}$ showed no significant difference in desorption kinetics from untreated soil.
\end{abstract}

Keywords: arsenate, sorption, desorption, oxalate, humic acid, kinetics

\section{Introduction}

Elevated arsenic (As) concentrations in soils can originate from mining and smelting industries, wastewater irrigation, and application of As-containing pesticides, herbicides and fungicides (Smith et al., 1998; Adriano, 2001). In some cases arsenic contaminated soil can present a potential to pollute surface water and groundwater or to enter the food chain through plant uptake and, therefore, has adverse effects on environmental and human health (Liu et al., 2001; Nordstrom, 2002). Mobility, toxicity and bioavailability of As in soils are largely controlled by its sorption. It is therefore important to study the sorption of arsenic in soils in order to elucidate the fate of As in soils.

Arsenic occurs in soils mainly as arsenate (As(V)), which makes up $90 \%$ of the dissolved As in aerobic soils (Smith et al., 1998). Arsenate has strong affinity for soil minerals and oxides, especially $\mathrm{Fe}$ and $\mathrm{Al}$ oxides and hydroxides (Livesey and

Water, Air, and Soil Pollution (2006) 176: 269-283

DOI: $10.1007 / \mathrm{s} 11270-006-9168-0$

(c) Springer 2006 
Huang, 1981; Violante and Pigna, 2002). Sorption of As(V) by soil minerals has been widely investigated and relevant mechanisms have been proposed (Anderson et al., 1976; Lumsdon et al., 1984; Fuller et al., 1993; Goldberg and Johnston, 2001). Additionally, a great deal of research has been conducted to examine the effects of $\mathrm{pH}$ and electrolyte type on $\mathrm{As}(\mathrm{V})$ sorption by soil minerals (Liu et al., 2001; Smith et al., 2002; Cornu et al., 2003). These studies mainly focused on soil minerals and the mechanisms were based on the As(V) reaction at the mineral-water interface. Soil is a heterogeneous mixture of organic matter, oxides, clay minerals and minerals and thus exerts complicated impacts on sorption of contaminants. Arsenate sorption on soil can not be explained completely by any of the mechanisms proposed for individual soil components. Therefore, the use of a whole soil to examine sorption mechanisms is necessary (Smith et al., 2002; Violante and Pigna, 2002; Jiang et al., 2005). The Chinese red soil, a main soil type in south China, shows a rather high sorption capacity for As(V) (Jiang et al., 2005). Research on the sorption and desorption of $\mathrm{As}(\mathrm{V})$ in the soil is therefore of particular necessity.

The influence of inorganic ligands on $\mathrm{As}(\mathrm{V})$ sorption on soil or soils minerals has been documented by some researchers (Liu et al., 2001; Violante and Pigna, 2002; Waltham and Eick, 2002). They found that As(V) sorption was significantly reduced in the presence of phosphate or silicic acid. However, research on the effects of organic ligands on $\mathrm{As}(\mathrm{V})$ sorption and desorption in soil is very limited (Liu et al., 2001). Soil, especially the rhizosphere soil, has a relatively high content of low molecular weight organic anions, such as oxalate (Jones, 1998; De Cristofaro et al., 2000). Humic acid accounts for a large part of soil organic carbon. Both of them are highly reactive toward metal oxides and clay minerals (Sibanda and Young, 1986; Bhatti et al., 1998a, b; De Cristofaro et al., 2000) and therefore may have a profound effect on $\mathrm{As}(\mathrm{V})$ sorption onto and desorption from soil. The only literature available for the effect of oxalate is a description of the phenomenon of competitive sorption of $\mathrm{As}(\mathrm{V})$ and oxalate on goethite (Liu et al., 2001) and the relevant mechanism is poorly understood. Several studies have reported the influence of HA on As(V) sorption. Saada et al. (2003) studied As(V) sorption to kaolinite and reported that HA might provide sorption sites for $\mathrm{As}(\mathrm{V})$, thus enhancing its sorption. Grafe et al. (2001) demonstrated that HA and other forms of dissolved organic carbon decreased $\mathrm{As}(\mathrm{V})$ sorption on goethite and should therefore increase the bioavailability of $\mathrm{As}(\mathrm{V})$ in soil and water systems regardless of $\mathrm{pH}$. Grafe et al. (2002) observed that the sorption processes of HA and $\mathrm{As}(\mathrm{V})$ on ferrihydrite were independent of each other and hence HA had no effect on As(V) sorption. These studies only reported the effects of HA on As(V) sorption on soil minerals and only considered arsenate sorption. Few data have been published on the effects of HA on arsenate sorption and desorption on soil.

The objective of this study was therefore to investigate (i) the $\operatorname{As}(\mathrm{V})$ sorption by and desorption from a Chinese red soil; (ii) the effects of HA and oxalate on the sorption and desorption of $\mathrm{As}(\mathrm{V})$; (iii) the effects of residence time on $\mathrm{As}(\mathrm{V})$ sorption and desorption in the presence of oxalate and HA. 


\section{Materials and Methods}

\subsection{Materials}

Soil was collected from the B horizon (15-30 cm depth) of a clay loam (Ultisol) in Jiangxi Province, southern China. Soil was air dried and passed through a 2-mm sieve. Total and amorphous iron and aluminum oxides were extracted by citratedithionite and ammonium oxalate, respectively, according to the method of Coffin (1963). Other properties for the soil, for example, $\mathrm{pH}$, soil organic carbon, particle size distribution, were determined using standard methods (Sparks, 1996). Crystalline clay minerals in the soil were analyzed by X-ray diffraction (XRD) with $\mathrm{Cu}-\mathrm{K} \alpha$ radiation. Selected properties of the soil are presented in Table 1.

Sodium arsenate and sodium oxalate were of analytical reagent grade from Beijing Chemical Co (Beijing, China). The humic acid used was a commercial HA from Aldrich Chemical, Inc (St. Louis, USA). All other reagents used were of analytical reagent grade or better. The HA was used without further purification. The contents of dissolved organic $\mathrm{C}$, total $\mathrm{C}$ and total $\mathrm{N}$ in the humic acid were $42.2 \%, 53.0 \%$ and $2.8 \%$, respectively.

\subsection{SORPTION ISOTHERMS}

Sorption isotherms were constructed to determine the sorption behavior for arsenate $(\mathrm{As}(\mathrm{V}))$ to the Chinese red soil at $\mathrm{pH} 6.0$ and a constant room temperature of $25^{\circ} \mathrm{C}$. Triplicate 1.00 -g soil samples were equilibrated with $20 \mathrm{~mL}$ of background electrolyte solution of $0.01 \mathrm{M} \mathrm{NaNO}_{3}$ containing an $\mathrm{As}(\mathrm{V})$ concentrations ranging from 0 to $2.0 \mathrm{mM}$ (from a stock solution of $10 \mathrm{mM}$ sodium arsenate in $0.01 \mathrm{M}$

TABLE I

Physicochemical properties of the soil

\begin{tabular}{lc}
\hline Property & \\
\hline $\mathrm{pH}\left(1: 1\right.$ in $\left.\mathrm{H}_{2} \mathrm{O}\right)$ & 5.3 \\
$\mathrm{SOC}(\%)$ & 0.66 \\
Oxalate-extractable & 3469 \\
$\mathrm{Fe}\left(\mathrm{mg} \mathrm{kg}^{-1}\right)$ & 1339 \\
$\mathrm{Al}\left(\mathrm{mg} \mathrm{kg}^{-1}\right)$ & \\
$\mathrm{Citrate}-\mathrm{dithionite-extractable}$ & \\
$\mathrm{Fe}\left(\mathrm{mg} \mathrm{kg}^{-1}\right)$ & 44995 \\
$\mathrm{Al}\left(\mathrm{mg} \mathrm{kg}^{-1}\right)$ & 42.6 \\
$\mathrm{Clay}(\%)$ & 50.4 \\
$\mathrm{SSA}\left(\mathrm{m}^{2} \mathrm{~g}^{-1}\right)$ & quartz, kaolinite, \\
Minerals & mica, iron oxides \\
\hline
\end{tabular}


$\mathrm{NaNO}_{3}$ at $\mathrm{pH}$ 6.0) in 50-mL polypropylene centrifuge tubes. A wide range of $\mathrm{As}(\mathrm{V})$ concentrations was selected in order to represent different contaminated conditions. Oxalate and HA were added, from stock solution and directly from the original reagent, respectively, to give initial concentrations of 1.0 or $10 \mathrm{mM}$ oxalate and 0.5 or $5.0 \mathrm{~g} \mathrm{~L}^{-1} \mathrm{HA}$. To understand the competition in sorption between $\mathrm{As}(\mathrm{V})$ and oxalate/HA, oxalate or HA was added in two ways, firstly by adding As(V) and oxalate/HA simultaneously and secondly by adding oxalate/HA in advance and shaking the soil suspension for $24 \mathrm{~h}$ and then adding the As(V). Two drops of toluene were added at the same time as the oxalate to inhibit soil microbial growth. The $\mathrm{pH}$ of the suspension was then adjusted to 6.0 and equilibrated for $24 \mathrm{~h}$ by shaking horizontally in darkness. The $\mathrm{pH}$ of the suspensions was kept constant by adjusting periodically using $0.1 \mathrm{M} \mathrm{HCl}$ when necessary. At the end of the equilibration period the suspensions were centrifuged at $7200 \times \mathrm{g}$ for $20 \mathrm{~min}$, filtered through a $0.45-\mu \mathrm{m}$ Millipore membrane, and analyzed for As (V), Fe, Al, $\mathrm{Si}$, inorganic $\mathrm{PO}_{4}{ }^{3-}(\mathrm{P})$, and dissolved organic carbon (DOC). For As sorption in the presence of oxalate or HA, the content of oxalate or DOC in the equilibrium solution was also determined. The amount of $\mathrm{As}(\mathrm{V})$ and oxalate or HA sorbed by the soils was calculated from the difference between the concentrations of the supernatant and those of the initial solutions. The amount of $\mathrm{OH}^{-}$released into solution during As $(\mathrm{V})$ sorption was also calculated using the method of Duquette and Hendershot (1993). In addition, specific surface areas of the soil samples treated with oxalate and $\mathrm{HA}$ as well as original soil were determined with a single-point BET $\mathrm{N}_{2}$ adsorption isotherm.

\subsection{Desorption of ARSENATE}

Since phosphate is ubiquitous in soils and could compete with $\mathrm{As}(\mathrm{V})$ for sorption sites (Violante and Pigna, 2002), it was used as a desorption reagent in the study. Therefore, desorption experiments were conducted by removing the equilibrium solution after centrifugation, replacing an equal volume of $6 \mathrm{mM}$ phosphate desorbing solution and shaking the mixture for $24 \mathrm{~h}$ in darkness with periodical adjustment of the $\mathrm{pH}$ to its initial value. The solid/solution ratio, ionic strength, $\mathrm{pH}$ of the solution, and sampling methods were the same as for the sorption studies. The total percentage of $\mathrm{As}(\mathrm{V})$ desorbed was calculated by comparing the differences between the $\mathrm{As}(\mathrm{V})$ adsorbed previously and the amount desorbed.

\subsection{SORPTION AND DESORPTION KINETICS}

Sorption kinetic experiments were performed with initial $\mathrm{As}(\mathrm{V})$ concentrations of 0.2 and $2.0 \mathrm{mM}$ at $\mathrm{pH} 6.0$ in the presence and absence of $10 \mathrm{mM}$ oxalate or 5.0 $\mathrm{g} \mathrm{L}^{-1} \mathrm{HA}$. Other parameters were the same as described for the sorption isotherm experiments. Samples were taken from the batch treatments over periods varying from $0.2 \mathrm{~h}$ to $840 \mathrm{~h}$. Desorption kinetics were conducted on the soil samples with 
sorption equilibrium times of $24 \mathrm{~h}$ and $840 \mathrm{~h}$ independently. Desorption time ranged from $0.5 \mathrm{~h}$ to $840 \mathrm{~h}$.

\subsection{ANALYSIS AND STATISTICS}

Arsenate in solutions was determined by hydride generation atomic fluorescence spectrometry (Beijing BRAIC, China). No As(III) was detected in the equilibrium solutions. $\mathrm{Fe}, \mathrm{Al}, \mathrm{P}$ and $\mathrm{Si}$ in the final solutions were determined by inductively coupled plasma atomic emission spectrometry (ICP-AES; OPTIMA2000DV, Perkin Elmer). Oxalate and phosphate were analyzed by a P/ACE MDQ capillary electrophoresis system from Beckman (Fullerton, CA, USA.) equipped with a UV detector. Dissolved organic carbon was determined by a Phoenix 8000 TOC analyzer.

All the data were obtained by analysis of triplicate subsamples. Statistical analysis was performed using SPSS (Statistical Package for Social Science) v. 10.0 and Origin 7.0.

\subsection{QUALITY ASSURANCE FOR ARSENIC DETERMINATION}

Quality assurance for As determination was carried out by the determination of total As in soil certified reference materials (GBW 07408 and GBW 08302) obtained from the National Research Center for Certified Reference Materials (Beijing, China). Seven replicate analyses were made of each reference material. The results obtained were $12.1 \pm 1.0 \mu \mathrm{g} \mathrm{g}^{-1}$ and $4.0 \pm 0.3 \mu \mathrm{g} \mathrm{g}^{-1}$ of As for GBW 07408 and GBW 08302 compared with the certified values of $12.7 \pm 1.7 \mu \mathrm{g} \mathrm{g}^{-1}$ and $3.8 \pm$ $0.4 \mu \mathrm{g} \mathrm{g}^{-1}$ of As. Our results were not statistically significantly different from the certified values $(p<0.01)$.

\section{Results and discussion}

\subsection{Arsenate SORPTION IN THE RED SOIL}

Sorption isotherms of $\mathrm{As}(\mathrm{V})$ in the red soil with and without oxalate or HA are presented in Figure 1. The lines represent the fits of the data to the Freundlich sorption isotherm equation (shown as the solid lines in Figure 1). The results from Freundlich equation fittings are listed in Table 2. The equation showed significant correlation with $\mathrm{R}$ values ranging from 0.996 to $0.998(p<0.01)$. The As(V) sorption generally increased with increasing initial $\mathrm{As}(\mathrm{V})$ concentrations from 0 to $2.0 \mathrm{mM}$, and the soil showed a rather higher sorption capacity for $\mathrm{As}(\mathrm{V})$ compared with the reported data for As(V) sorption on soils (Livesey and Huang, 1981; Jiang et al., 2005). The XRD analysis indicated only minor amounts of iron oxides in the soil. However, the ratios of oxalate to citrate-dithionate extractable $\mathrm{Al}$ and $\mathrm{Fe}$ 
TABLE II

Parameters of the Freundlich equation for $\mathrm{As}(\mathrm{V})$ sorption by the soil in the presence and absence of oxalate or HA

\begin{tabular}{|c|c|c|c|}
\hline & $K\left(\mathrm{mmol}^{1-n} \mathrm{~L}^{n} \mathrm{~kg}^{-1}\right)$ & $n$ & $r^{2}$ \\
\hline Original soil & $11.03 \pm 0.20$ & $0.298 \pm 0.013$ & 0.995 \\
\hline Soil +0.001 M Oxalate & $7.07 \pm 0.10$ & $0.415 \pm 0.017$ & 0.995 \\
\hline Soil + 0.01 M Oxalate & $6.26 \pm 0.12$ & $0.401 \pm 0.022$ & 0.992 \\
\hline Soil + Pre-0.01 M Oxalate & $8.31 \pm 0.10$ & $0.358 \pm 0.012$ & 0.997 \\
\hline Soil $+0.5 \mathrm{~g} \mathrm{~L}^{-1} \mathrm{HA}$ & $6.78 \pm 0.09$ & $0.413 \pm 0.016$ & 0.996 \\
\hline Soil $+5 \mathrm{~g} \mathrm{~L}^{-1} \mathrm{HA}$ & $6.96 \pm 0.12$ & $0.399 \pm 0.020$ & 0.993 \\
\hline Soil + Pre-5 g L ${ }^{-1} \mathrm{HA}$ & $8.81 \pm 0.10$ & $0.367 \pm 0.012$ & 0.997 \\
\hline
\end{tabular}

$K$ is the Freundlich sorption coefficient and $n$ (dimensionless) describes isotherm curvature.

( 0.30 for $\mathrm{Al}$ and 0.14 for $\mathrm{Fe}$ ) suggested that significant proportions of $\mathrm{Al}$ and $\mathrm{Fe}$ were in forms of low crystallinity (Johnson et al., 1986). This accounted for the high sorption capacity of the soil (Livesey and Huang, 1981; Jiang et al., 2005).

With the increasing $\mathrm{As}(\mathrm{V})$ sorption, significant enhancements in the release of dissolved organic carbon (DOC) and the major inorganic anions, such as $\mathrm{OH}^{-}$and $\mathrm{PO}_{4}{ }^{3-}$, were observed (Table 3). Arsenate sorption could account for the release of the anions from the soil through the ligand exchange with soil organic carbon and other anions (Arai et al., 2005). Weakly complexed anions and some of the soil organic carbon (mainly aliphatic carboxyl) on the soil surface could be substituted by $\mathrm{As}(\mathrm{V})$ via competition for the sorption sites because both $\mathrm{As}(\mathrm{V})$ and the anions could occupy common sorption sites (Anderson et al., 1976; Livesey and Huang, 1981; Arai et al., 2005). Surface precipitates might also occur in the soil since the bulk solution was far beyond saturation with respect to the solubility of iron or aluminium arsenate (Livesey and Huang, 1981; Fuller et al., 1993). However, if precipitation predominated in the soil, we would not expect the obvious enhancement in the release of dissolved $\mathrm{Al}$ and $\mathrm{Fe}$ since these cations would otherwise precipitate with $\mathrm{As}(\mathrm{V})$ in the system. Table 3 shows an increase in the dissolved $\mathrm{Fe}$ and $\mathrm{Al}$ with increasing $\mathrm{As}(\mathrm{V})$ sorption together with a parallel increase in DOC. Some of the organic ligands released from the soil along with $\mathrm{As}(\mathrm{V})$ sorption could chelate metal ions in solution, such as $\mathrm{Fe}$ and $\mathrm{Al}$, resulting in the release of $\mathrm{Fe}$ and $\mathrm{Al}$ ions from the soil surface in turn.

\subsection{EFFECTS OF OXALATE AND HA ON THE SORPTION OF ARSENATE IN THE SOIL}

Arsenate sorption significantly decreased in the presence of oxalate or HA (Figure 1), and the maximum reductions of $36.7 \%$ and $40.1 \%$ were obtained in the presence of $10 \mathrm{mM}$ oxalate and $5.0 \mathrm{~g} \mathrm{~L}^{-1} \mathrm{HA}$, respectively, indicating that both oxalate and HA could suppress As(V) sorption. 

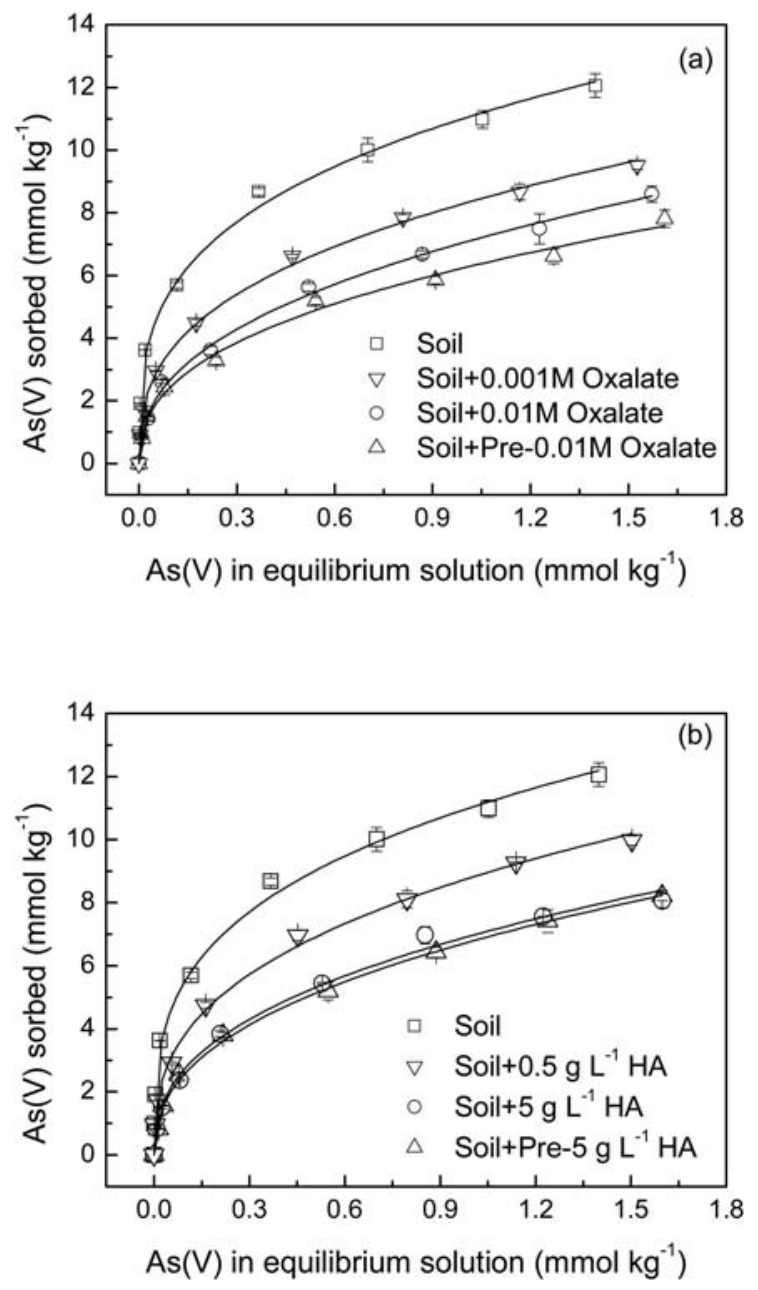

Figure 1. Arsenate sorption isotherms of the red soil in the presence and absence of (a) oxalate, (b) $\mathrm{HA}$ at $\mathrm{pH}$ 6.0. Background electrolyte: $0.01 \mathrm{M} \mathrm{NaNO}_{3}$; solid/solution: $50 \mathrm{~g} \mathrm{~L}^{-1}$. Pre-indicates oxalate or humic acid addition $24 \mathrm{~h}$ before $\mathrm{As}(\mathrm{V})$ addition.

Because of the complex nature of soil components, the effect of oxalate or HA on $\mathrm{As}(\mathrm{V})$ sorption could result from different factors. First, in a similar way to As $(V)$, oxalate could be retained on soil surfaces through ligand exchange (Bhatti et al., 1998b). Humic acid is rich in phenolic/catecholic $\mathrm{OH}^{-}$and may also compete with $\mathrm{As}(\mathrm{V})$ for surface sorption sites (Grafe et al., 2001). So oxalate and HA could inhibit $\mathrm{As}(\mathrm{V})$ sorption in soil through competition for sorption sites. Figure 2 shows the relationship between the sorption of $\mathrm{As}(\mathrm{V})$ and oxalate/HA. There was a significant negative correlation between oxalate/HA and $\mathrm{As}(\mathrm{V})$ sorbed with correlation coefficients $(\mathrm{R})$ of 0.986 for oxalate and 0.990 for HA $(p<0.01)$. Competition 
TABLE III

Release of $\mathrm{Fe}, \mathrm{Al}, \mathrm{OH}^{-}, \mathrm{Si}, \mathrm{PO}_{4}{ }^{3-}$, and dissolved organic $\mathrm{C}$ (DOC) from the soil during the $\mathrm{As}(\mathrm{V})$ sorption isotherm in the absence of oxalate or $\mathrm{HA}$ at $\mathrm{pH} 6.0$.

\begin{tabular}{lllllll}
\hline \multirow{2}{*}{$\begin{array}{l}\text { As(V) added } \\
\left(\mathrm{mmol} \mathrm{kg}^{-1} \text { soil }\right)\end{array}$} & \multicolumn{5}{c}{ Amount released $\left(\mathrm{mmol} \mathrm{kg}^{-1}\right.$ soil $)$} \\
\cline { 2 - 7 } & $\mathrm{Fl}$ & $\mathrm{Si}$ & $\mathrm{PO}_{4}^{-3}$ & $\mathrm{DOC}$ & $\mathrm{OH}^{-}$ \\
\hline 0 & 0.01 & 0.16 & 0.67 & 0.001 & 17.3 & 0 \\
1 & 0.02 & 0.21 & 0.84 & 0.003 & 18.1 & 1.34 \\
2 & 0.03 & 0.25 & 0.93 & 0.004 & 18.6 & 2.27 \\
4 & 0.05 & 0.29 & 0.97 & 0.005 & 19.1 & 4.23 \\
8 & 0.12 & 0.60 & 0.99 & 0.008 & 20.0 & 5.16 \\
16 & 0.23 & 0.75 & 1.34 & 0.014 & 21.1 & 9.70 \\
24 & 0.25 & 0.82 & 1.54 & 0.018 & 22.6 & 11.6 \\
32 & 0.27 & 0.91 & 1.71 & 0.029 & 24.8 & 13.7 \\
40 & 0.31 & 1.04 & 1.85 & 0.030 & 26.3 & 14.4 \\
\hline
\end{tabular}

The measurements were in triplicate, with the uncertainty being generally less than $\pm 5 \%$.

between $\mathrm{As}(\mathrm{V})$ and oxalate/HA became more evident with increasing $\mathrm{As}(\mathrm{V})$ added to the solution, and more sorption sites occupied by oxalate/HA were replaced by As $(\mathrm{V})$ since the amounts of oxalate/HA amendments were constant. Oxalate or HA released could form soluble complexes with $\mathrm{Fe}$ and $\mathrm{Al}$, thus with the increase in oxalate and HA in solution caused by sorption, the release of Fe and Al significantly increased $(p<0.01)$.

Arsenate sorption declined more when oxalate was added $24 \mathrm{~h}$ before As(V) addition compared with the results for simultaneous addition of oxalate and $\mathrm{As}(\mathrm{V})$. But the difference was not significant for HA. It has been confirmed that both oxalate/HA and As(V) sorption are time-dependent (Fox et al., 1990; O'Reilly et al., 2001). If competition for sorption sites was the only way that oxalate/HA affected $\mathrm{As}(\mathrm{V})$ sorption, such effects should also be affected by residence time and we would not get the conflicting data on the comparative effects of oxalate and HA sorption. The results suggested that oxalate and HA could exert influence on $\mathrm{As}(\mathrm{V})$ sorption in some other ways apart from competition for sorption sites. Dissolution of clay minerals including poorly crystalline (amorphous) $\mathrm{Fe}$ and $\mathrm{Al}$ oxides and thus decrease in sorption sites could also occur when oxalate or HA is added. Organic acids, especially the simple aliphatic acids such as oxalate have been observed to accelerate the dissolution of mineral surfaces (Jones, 1998; Eick et al., 1999). Comparing Table 3 and Figure 2, we can see a great differences in $\mathrm{Fe}$ and $\mathrm{Al}$ concentrations between the systems with and without oxalate or HA. If the soluble Fe and $\mathrm{Al}$ were only caused by complexation, we would not expect such big differences. Specific surface area determination shows the specific surface area of the soil was reduced by $33.8 \%$ with oxalate and by $59.6 \%$ with 


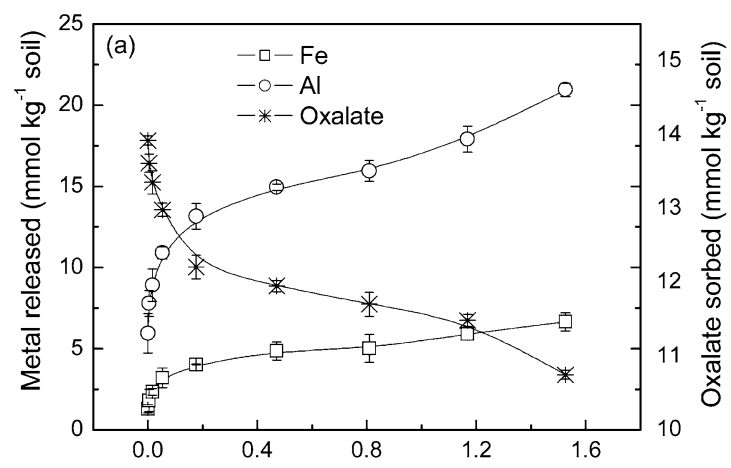

Arsenate in equilibrium solution $\left(\mathrm{mmol} \mathrm{kg}^{-1}\right)$

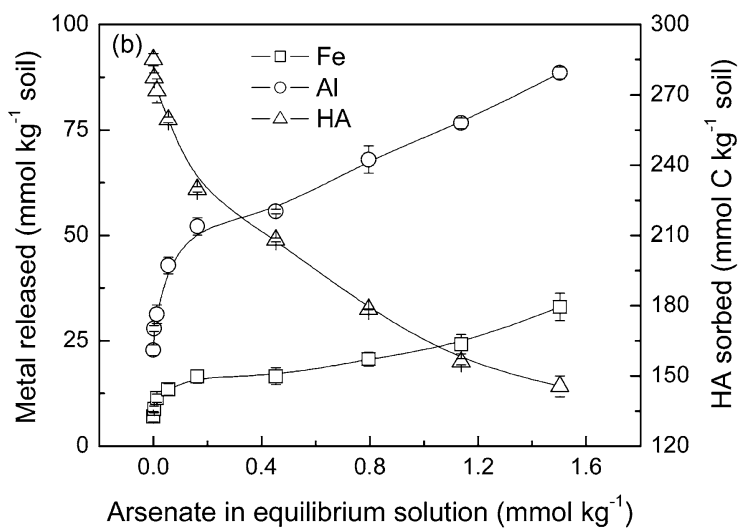

Figure 2. Relationships among oxalate (a)/ HA (b) sorption and amount of $\mathrm{Fe}$, and $\mathrm{Al}$ released during the $\mathrm{As}(\mathrm{V})$ sorption isotherms at $\mathrm{pH} 6.0$ shown in Figure 1. Concentrations of oxalate and HA added were $1.0 \mathrm{mM}$ and $0.5 \mathrm{~g} \mathrm{~L}^{-1}$, respectively.

HA after equilibration for $24 \mathrm{~h}$, thus indicating that oxalate and HA amendments significantly affected the soil surface characteristics and consequently the number of sorption sites (Kaiser and Guggenberger, 2003). Humic acid could also enhance soil aggregation possibly by bridging or flocculation, which could improve soil structure and thus reduce sorption sites (Piccolo and Mbagwu, 1999; Bronick and Lal, 2005). However, such an effect might be minor compared with the mineral dissolution by oxalate.

\subsection{EFFects of OXAlate AND HA ON ARSENATE DESORPTION}

Figure 3 shows $\mathrm{As}(\mathrm{V})$ desorption by $6 \mathrm{mM}$ phosphate at $\mathrm{pH}$. After $24 \mathrm{~h}$ only about 35 to $55 \%$ of the adsorbed $\mathrm{As}(\mathrm{V})$ was desorbed because of its high affinity for soil components (Violante and Pigna, 2002). The amounts of $\mathrm{As}(\mathrm{V})$ desorbed from the 
sorption subsamples tended to increase with increasing $\mathrm{As}(\mathrm{V})$ loadings. However, the changes in the desorption ratio, defined as the ratio of the desorbed fraction to the total amount of $\mathrm{As}(\mathrm{V})$ adsorbed, were not obvious at the various $\mathrm{As}(\mathrm{V})$ concentrations studied, indicating that as the amount of $\mathrm{As}(\mathrm{V})$ absorbed increased, the desorbed fraction also increased correspondingly. The desorption ratio of $\mathrm{As}(\mathrm{V})$ in the presence of oxalate or HA was about $10 \%$ higher than that without oxalate or HA. The phenomenon that adsorbed $\mathrm{As}(\mathrm{V})$ were more easily desorbed in the presence of oxalate or HA could be attributed to the reduction in sorption sites because of the effects of oxalate or HA on the soil surface characteristics (Kaiser and Guggenberger, 2003). In addition, the oxalate or HA sorbed on the subsamples could be released into the solution in the desorption process (Sibanda and Young, 1986; Bhatti et al., 1998a; Violante and Pigna, 2002) and thus would also facilitate As(V) desorption.

\subsection{KinetiCS OF ARSENATE SORPTION AND DESORPTION IN THE PRESENCE OF OXALATE AND HA}

Figure 4 shows the kinetics of $\mathrm{As}(\mathrm{V})$ sorption in soil in the presence and absence of oxalate and $\mathrm{HA}$ at $\mathrm{pH} 6.0$ with $\mathrm{As}(\mathrm{V})$ concentrations of 0.2 and $2.0 \mathrm{mM}$ over a period of $0.2 \mathrm{~h}$ to $840 \mathrm{~h}$. Arsenate sorption was characterized by an initial fast and then a very slow rate of sorption. The two-stage sorption kinetics observed in this experiment was similar to the results for $\mathrm{As}(\mathrm{V})$ sorption on goethite reported by O’Reilly et al. (2001).

In the presence of oxalate or $\mathrm{HA}, \mathrm{As}(\mathrm{V})$ sorption within $24 \mathrm{~h}$ was decreased by $34.6 \%$ and $36.2 \%$, respectively, for the samples with the initial $\mathrm{As}(\mathrm{V})$ loading of

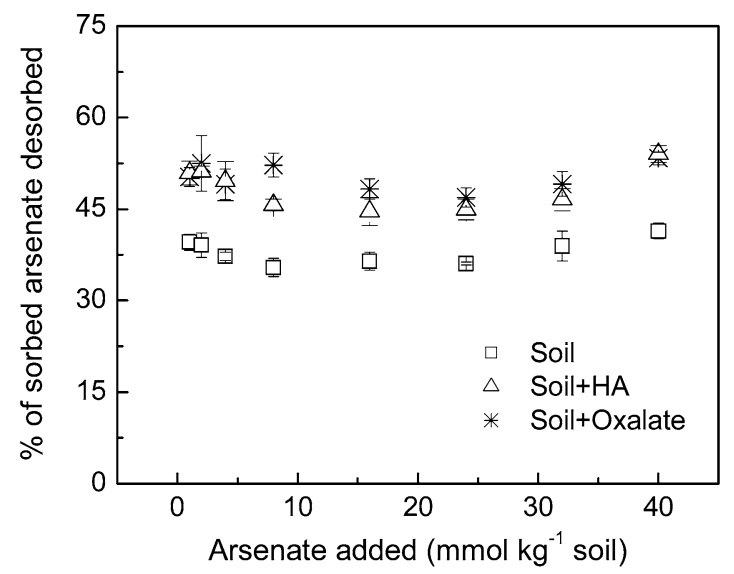

Figure 3. Desorption of $\mathrm{As}(\mathrm{V})$ by phosphate $(6.0 \mathrm{mM})$ at $\mathrm{pH}$ 6.0. Background electrolyte: $0.01 \mathrm{M}$ $\mathrm{NaNO}_{3}$; solid/solution: $50 \mathrm{~g} \mathrm{~L}^{-1}$. The desorption samples had been incubated with $24 \mathrm{~h}$ in the presence and absence of oxalate or HA. 

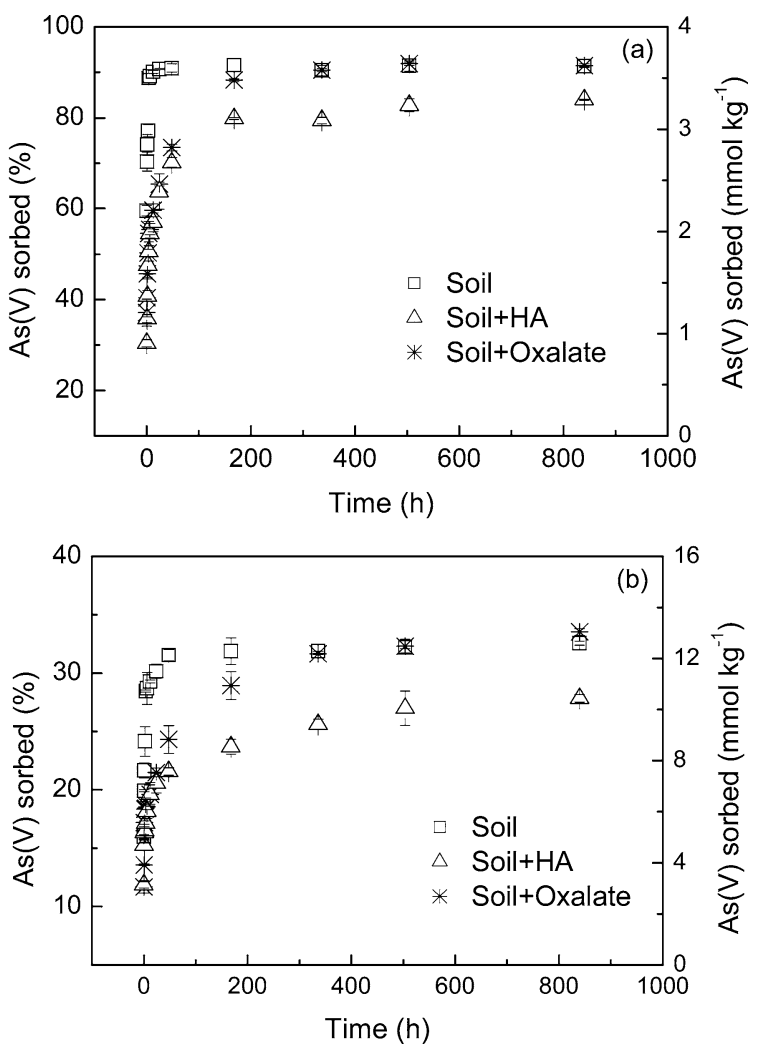

Figure 4. Arsenate [(a) $0.2 \mathrm{mM}$, (b) $2.0 \mathrm{mM}$ ] sorption kinetics in the red soil in the presence of oxalate and $\mathrm{HA}$ at $\mathrm{pH}$ 6.0. Background electrolyte: $0.01 \mathrm{M} \mathrm{NaNO}_{3}$; solid/solution: $50 \mathrm{~g} \mathrm{~L}^{-1}$.

$0.2 \mathrm{mM}$. Similar results were obtained for the samples with $2.0 \mathrm{mM}$ As(V) loading. At the same time, sorption equilibrium was retarded and the maximum As(V) sorption decreased by $8.1 \%$ and $16.1 \%$ in the presence of HA at $\mathrm{As}(\mathrm{V})$ loadings of 0.2 and $2.0 \mathrm{mM}$. This phenomenon could be attributed to the surface complexes and competition for sorption sites as well as the unfavorable electrostatic field generated from HA sorption (Sibanda and Young, 1986). No effect of oxalate was observed on $\mathrm{As}(\mathrm{V})$ sorption after a long equilibrium period, which could be the result of biodegradation of oxalate by soil microbes (Fox et al., 1990). Although toluene was added to retard microbial growth in the samples in our study, microbial activity was inhibited for only a short time (O'Keefe et al., 1987).

Arsenate desorption kinetics (Figure 5) was also characterized by an initial fast and then a slower reaction. More than $41 \%$ and $35 \%$ of $\mathrm{As}(\mathrm{V})$ were desorbed within $24 \mathrm{~h}$ for the samples without oxalate or HA for $24 \mathrm{~h}$ and $840 \mathrm{~h}$ equilibrium time, respectively, followed by a small amount of additional desorption during the subsequent period of the experiments. There were apparent effects of both sorption 

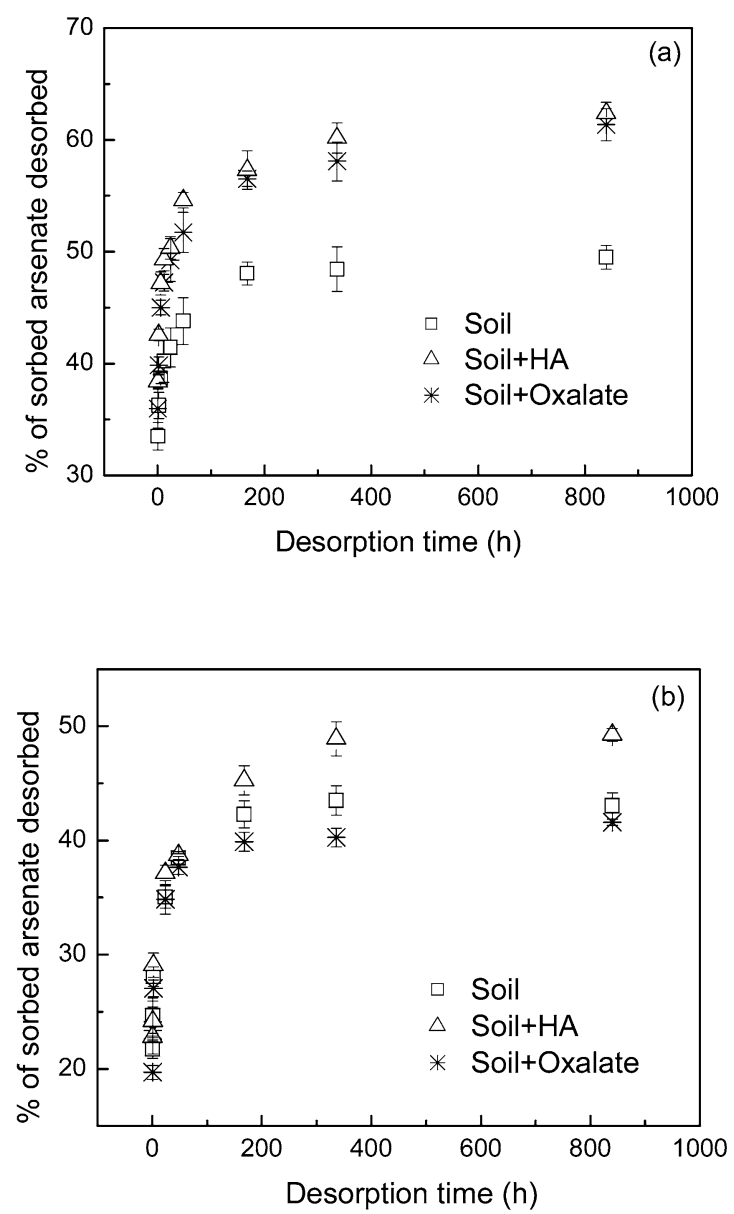

Figure 5. Arsenate desorption kinetics by phosphate $(6.0 \mathrm{mM})$ at $\mathrm{pH}$ 6.0. Background electrolyte: $0.01 \mathrm{M} \mathrm{NaNO}_{3}$; solid/solution: $50 \mathrm{~g} \mathrm{~L}^{-1}$. The samples had been incubated with sorption residence times of (a) $24 \mathrm{~h}$ and (b) $840 \mathrm{~h}$ in the presence and absence of oxalate or HA.

equilibrium time and the presence of oxalate or HA on $\mathrm{As}(\mathrm{V})$ desorption. The slow desorption reactions were more noticeable for the samples with longer equilibrium times. After $840 \mathrm{~h}$ the total desorption ratio reached about $50 \%$ and $41 \%$ for the samples with the sorption equilibrium time of $24 \mathrm{~h}$ and $840 \mathrm{~h}$, respectively. The results indicate that a significant amount of $\mathrm{As}(\mathrm{V})$ was still retained in the soil even after $840 \mathrm{~h}$ of desorption since the phosphate added was three times higher than the initial $\mathrm{As}(\mathrm{V})$ concentration for the sorption experiments, which is in agreement with the observations of O'Reilly et al. (2001).

The previously sorbed oxalate and HA facilitated the desorption of As(V) from soil. Due to the degradation, oxalate had no significant influence on desorption kinetics for the samples with a residence time of $840 \mathrm{~h}$. While HA always promoted 
As(V) desorption from soil mainly through affecting soil surface characteristics as stated above. Similar desorption kinetics were obtained from the sorption samples at the lower $\mathrm{As}(\mathrm{V})$ loading $(0.2 \mathrm{mM})$ (data not shown).

\section{Conclusions}

Our results illustrate several important aspects of the sorption and desorption of $\mathrm{As}(\mathrm{V})$ in this Chinese red soil. Arsenate was strongly sorbed mainly through ligand exchange on the soil. The presence of oxalate/HA retarded the sorption equilibrium, decreased the maximum sorption and increased the desorption of $\mathrm{As}(\mathrm{V})$ from soil. Oxalate and $\mathrm{HA}$ affected $\mathrm{As}(\mathrm{V})$ sorption on the soil through competition for sorption sites and reduction of sorption sites, and the effect of these mechanisms were not completely the same. Oxalate and HA could also facilitate $\mathrm{As}(\mathrm{V})$ desorption from the soil. Kinetic studies revealed that $\mathrm{As}(\mathrm{V})$ sorption involved an initial fast and then a subsequent slow sorption reaction. Oxalate and HA exerted similar effects on sorption and desorption kinetics of $\mathrm{As}(\mathrm{V})$ in the soil.

\section{Acknowledgements}

This work was funded by the National Natural Science Foundation of China (Project No. 20377049 and No.20237010).

\section{References}

Adriano, D.C. (2001). Trace elements in terrestrial ecosystems, Springer, New York.

Anderson, M.A., Ferguson, J.F., \& Gavis, J. (1976). Arsenate adsorption on amorphous aluminum hydroxide. Journal of Colloid and Interface Science, 54, 391-399.

Arai, Y., Sparks, D.L., \& Davis, J. A. (2005). Arsenate adsorption mechanisms at the allophone-water interface. Environmental Science and Technology, 39, 2537-2544.

Bhatti, J.S., Comerford, N.B., \& Johnston, C.T. (1998a). Influence of oxalate and soil organic matter on sorption and desorption of phosphate onto a spodic horizon. Soil Science Society of American Journal, 62, 1089-1095.

Bhatti, J.S., Comerford, N.B., \& Johnston, C.T. (1998b). Influence of soil organic matter removal and $\mathrm{pH}$ on oxalate sorption onto a spodic horizon. Soil Science Society of American Journal, 62, $152-158$

Bronick, C.J. \& Lal, R. (2005). Soil structure and management: a review. Geoderma, 124, 3-22.

Coffin, D.E. (1963). A method for the determination of free iron in soils and clays. Canadian Journal of Soil Science, 43, 7-17.

Cornu, S., Breeze, D., Saada, A., \& Baranger, P. (2003). The influence of pH, electrolyte type, and surface coating on arsenate (V) adsorption onto kaolinites. Soil Science Society of American Journal, 67, 1127-1132.

De Cristofaro, A., He, J.Z., Zhou, D.H., \& Violante, A. (2000). Adsorption of phosphate and tartrate on hydroxy-aluminum-oxalate precipitates. Soil Science Society of American Journal, 64, 13471355. 
Duquette, M., \& Hendershot, M. (1993). Soil surface charge evaluation by back-titration: I. Theory and method development. Soil Soil Science Society of American Journal, 57, 1222-1228.

Eick, M.J., Peak, J.D., \& Brady, W.D. (1999). The effects of oxyanions on the oxalate-promoted dissolution of goethite. Soil Science Society of American Journal, 63, 1133-1141.

Fox, T.R., Comerford, N.B., \& McFee, W.W. (1990). Kinetics of phosphorus release from Spodosols: Effects of oxalate and formate. Soil Science Society of American Journal, 54, 1441-1447.

Fuller, C.C., Davis, J.A., \& Waychunas, G.A. (1993). Surface chemistry of ferrihydrite: Part 2. Kinetics of arsenate adsorption and coprecipitation. Geochim. Acta. 57, 2271-2282.

Goldberg, S. \& Johnston, C. T. (2001). Mechanisms of arsenate adsorption on amorphous oxides evaluated using macroscopic measurements, vibrational spectroscopy, and surface complexation modeling. Journal of Colloid and Interface Science, 234, 204-216.

Grafe, M., Eick, M.J., \& Grossl, P.R. (2001). Adorption of arsenate (V) and arsenite (III) on goethite in the presence and absence of dissolved organic carbon. Soil Science Society of American Journal, $65,1680-1687$.

Grafe, M., Eick, M.J., Grossl, P.R., \& Saunders, A.M. (2002). Adsorption of arsenate and arsenite on ferrihydrite in the presence and absence of dissolved organic carbon. Journal of Environmental Quality, 31, 1115-1123.

Jiang, W., Zhang, S., Shan, X., Feng, M., Zhu, Y., \& McLaren, R.G. (2005). Adsorption of arsenate on soils. Part 2: Modeling the relationship between adsorption capacity and soil physiochemical properties using 16 Chinese soils. Environmental Pollution, 138, 285-289.

Johnson, D.W., Cole, D.W., Miegroet, H.V., \& Horng, F.W. (1986). Factors affecting anion movement and retention in four forest soils. Soil Science Society of American Journal, 50, 776-783.

Jones, D.L. (1998). Organic acid in the rhizosphere-a critical review. Plant Soil, 205, 25-44.

Kaiser, K. \& Guggenberger, G. (2003). Mineral surfaces and soil organic matter. European Journal of Soil Science, 54, 219-236.

Liu, F., De Cristofaro, A., \& Violante, A. (2001). Effect on pH, phosphate and oxalate on the adsorption/desorption of arsenate on/from goethite. Soil Science, 166, 197-208.

Livesey, N.T., \& Huang, P.M. (1981). Adsorption of arsenate by soils and its relation to selected chemical properties and anions. Soil Science, 131, 88-94.

Lumsdon, D.G., Fraser, A.R., Russell, J.D., \& Livesey, N.T. (1984). New infrared band assignments for the arsenate ion adsorbed on synthetic goethite $(\alpha-\mathrm{FeOOH})$. Journal of Soil Science, 35, 381-386.

Nordstrom, D.K. (2002). Worldwide occurrences of arsenate in ground water. Science, 296, 21432145.

O'Keefe, D., Fox, T.R., \& Will, M.E. (1987). An evaluation of microbial inhibitors in P sorption studies. In Agronomy abstracts (pp. 189). ASA, Madison, WI.

O'Reilly, S.E., Strawn, D.G., \& Sparks, D.L. (2001). Residence time effects on arsenate adsorption/desorption mechanisms on goethite. Soil Science Society of American Journal, 65, 67-77.

Piccolo, A. \& Mbagwu, J.S.C. (1999). Role of hydrophobic components of soil organic matter in soil aggregate stability. Soil Science Society of American Journal, 63, 1801-1810.

Saada, A., Breeze, D., Crouzet, C., Cornu, S., \& Baranger, P. (2003). Adsorption of arsenate (V) on kaolinite and on kaolinite-humic acid complexes: Role of humic acid nitrogen groups. Chemosphere, 51, 757-763.

Sibanda, H.M. \& Young, S.D. (1986). Competitive adsorption of humic acids and phosphate on goethite, gibbsite and two tropical soils. Journal of Soil Science, 37, 197-204.

Smith, E., Naidu, R., \& Alston, A.M. (1998). Arsenic in the soil environment: A review. Advance Agronomy, 64, 149-195.

Smith, E., Naidu, R., \& Alston, A.M. (2002). Chemistry of inorganic arsenic in soils: II. Effects of phosphorus, sodium, and calcium on arsenic sorption. Journal of Environmental Quality, 31, $557-563$. 
Sparks, D.L. (1996). Methods of soil analysis: Chemical methods. SSSA Book series, SSSA, Madison, WI.

Violante, A. \& Pigna, M. (2002). Competitive sorption of arsenate and phosphate on different clay minerals and soils. Soil Science Society of American Journal, 66, 1788-1796.

Waltham, C.A., \& Eick, M.J. (2002). Kinetics of arsenate adsorption on goethite in the presence of sorbed silicic acid. Soil Science Society of American Journal, 66, 818-825. 